\title{
Upregulation of heme oxygenase 1 (HO-1) attenuates kidney damage, oxidative stress and inflammatory reaction during renal ischemia/ reperfusion injury
}

\author{
Mai Barakat ${ }^{1}$, Mahmoud M. Gabr², Faten Zhran ${ }^{3}$, Mohamed El-Adl' ${ }^{1}$, Abdelaziz M. Hussein ${ }^{4}$, \\ Nashwa Barakat ${ }^{2}$ and Reda Eldemerdash ${ }^{2}$ \\ ${ }^{1}$ Department of Biochemistry and Chemistry of Nutrition, Faculty of Veterinary Medicine, Mansoura University, Mansoura, \\ Egypt \\ ${ }^{2}$ Urology and Nephrology Center, Mansoura University, Mansoura, Egypt \\ ${ }^{3}$ Department of Biochemistry, Faculty of Science, Zagazeg University, Zagazeg, Egypt \\ ${ }^{4}$ Department of Medical Physiology, Faculty of Medicine, Mansoura University, Mansoura, Egypt
}

\begin{abstract}
The current study investigated the effect of upregulation of heme oxygenase 1 (HO-1) by cobalt protoporphyrin (CoPP) on renal dysfunctions in renal ischemia/reperfusion (I/R) injury and its underlying mechanisms. 72 male Sprague Dawley rats were divided into 4 groups: sham group, ischemic group (left 45-min renal ischemia), CoPP-before group (as ischemic group with CoPP $20 \mathrm{mg} /$ $\mathrm{kg} 30 \mathrm{~min}$ before ischemia) and CoPP-after group (as ischemic group with CoPP $20 \mathrm{mg} / \mathrm{kg} 20 \mathrm{~min}$ after ischemia). Serum creatinine, urea and TGF- $\beta 1$ and markers of redox state (MDA, SOD, GSH and CAT), nitric oxide (NO), TGF- $\beta 1$ and HO-1 in kidney tissues were measured. Serum creatinine and urea levels were significantly increased in ischemic group and attenuated in CoPP-treated groups $(p<0.05)$. Also, markers of redox state showed significant deteriorations in ischemic group which were improved significantly in CoPP-treated groups $(p<0.05)$. HO- 1 expression in kidney tissues showed significant increase in ischemic group and showed more significant increase in CoPP-treated groups $(p<0.05)$. Moreover, serum and renal TGF- $\beta 1$ levels were significantly increased in ischemic group and attenuated in CoPP-treated groups $(p<0.05)$. We concluded that up-regulation of HO-1 by CoPP treatment before and after renal I/R injury improved the kidney function and morphology and this might be due to impairment of oxidative stress and inflammatory cytokines in kidney tissues.
\end{abstract}

Key words: Renal ischemia - TGF- $\beta 1-$ Heme oxygenase $1-$ Oxidative stress

\section{Introduction}

Renal warm ischemia/reperfusion (I/R) injury can occur in numerous clinical conditions, for example aortic crossclasping (juxta-renal or suprarenal aortic-cross clamping for stomach aortic aneurysms), fractional nephrectomy, kidney transplantation, enucleation of renal cell carcinoma, kidney vascular surgery and systemic hypoperfusion e.g. acute

Correspondence to: Abdelaziz M. Hussein, Department of Medical Physiology, Faculty of Medicine, Mansoura University, Mansoura, Egypt

E-mail: zizomenna28@yahoo.com menhag@mans.edu.eg myocardial infarction (Weight et al. 1998, 2001; Saito and Miyagawa 2000). Mechanisms underlying renal I/R injury includes energy depletion, high intracellular $\mathrm{Ca}^{2+}$, mitochondrial dysfunctions, production of reactive oxygen species (ROS) and pro-inflammatory cytokines leading to renal tubular cell death by apoptosis or necrosis (Shokeir et al. 2014, Hussein et al. 2016). Although, extensive research was done to understand its underlying mechanisms, effective therapy for its management is still deficient. So, new molecules and therapies are needed to be explored for its management.

Heme oxygenase $(\mathrm{HO})$ is the rate limiting enzyme of heme oxidation which produces several biologically active molecules such as biliverdin, carbon monoxide (CO) and ferrous ion (Maines, 1988). Three isoforms of $\mathrm{HO}$ are existed, HO-1, 
HO-2, and HO-3. Several previous studies demonstrated cytoprotective role for HO- 1 in heart and brain. Overexpression of HO-1 in either transgenic (Yet et al. 2001; Wang et al. 2010; Juhasz et al. 2011) or transfected rodents (Liu et al. 2006, 2007) or its induction by cobalt protoporphyrin IX (CoPP) (Lakkisto et al. 2010) reduced significantly the infarct size and ventricular remodeling and improved the myocardial and vascular functions in myocardial infarction animal models. Kusmic et al. (2014) demonstrated that upregulation of HO-1 by cobalt protoporphyrin (CoPP) improved the animal mortality and ventricular remodeling and preserved connexin 43 expression in myocardial infarction in rats. It has been also shown that the use of CoPP diminished lipopolysaccharide (LPS)/interleukin 13 (IL-13)-prompted microglial death (Fu et al. 2015; Lin et al. 2016). So, we hypothesized that upregulation of HO-1 by CoPP in kidney could protect it against renal I/R. Therefore, this study aimed to investigate the possible renoprotective effects of HO-1 upregulation by CoPP against renal I/R injury in addition to its effects on markers of redox state (MDA, GSH, CAT and SOD), NO and HO-1 and TGF- $\beta 1$ in kidney tissues.

\section{Materials and Methods}

\section{Experimental animals}

This work included 72 male Sprague Dawley rats weighing 200-300 g and aged 4-6 months. They were reared in the research animal facility in the Nile Center for Experimental Research (NCER) at Mansoura, Egypt and kept on a $12 \mathrm{~h}$ (light-dark cycle). Animals were fed on standard eating regimen and water. All experimentations were led as per the NIK Guide for the Care and Use of Laboratory Animals and approved by our local Committee for Animal Care and ethics.

\section{Study design}

Randomly the animals were allocated into 4 equal groups as follow:

1) Sham group $(n=18)$ : rats underwent right nephrectomy without left renal ischemia.

2) Ischemic group $(n=18)$ : rats underwent right nephrectomy with left renal ischemia last for 45 minutes.

3) Cobalt-protoporphyrin (CoPP)-before group $(n=18)$ : as ischemic group with CoPP $(20 \mathrm{mg} / \mathrm{kg}$ ) (Sigma Chemical Company (St.Louis, MO, USA) intraperitoneally (i.p.) 30 minutes before ischemia.

4) Cobalt-protoporphyrin (CoPP)-after group ( $n=18)$ : as ischemic group with CoPP $(20 \mathrm{mg} / \mathrm{kg})$ i.p. $20 \mathrm{~min}$ after renal ischemia.

Each group was split up into 3 sub-groups according to the time of sacrifice: $24 \mathrm{~h}, 48 \mathrm{~h}$ and 7 days.

\section{Animal model of renal ischemia}

Anesthesia of rats was induced by keeping in a metal container with a piece of cotton soaked with $10 \mathrm{ml}$ of halothane 30 seconds, then maintained on i.p. sodium thiopental (12 mg/100 g b.w.). Details of surgical procedures of 45-min renal ischemia and sham operation were described in our previous work (Hussein et al. 2016).

\section{Blood sample collection and serum creatinine and urea measurement}

Blood samples were obtained from inner canthus of the eye by fine tipped pasture pipette under light halothane anesthesia at end of experiment for each subgroup. Blood sample was separated into 2 parts (one part stored on EDTA-anticoagulant and the second part was placed on vacuum tube), then centrifuged to obtain serum for serum creatinine and urea levels measurement and lymphocytes for Transforming growth factor- $\beta 1$ (TGF- $\beta 1$ ) measurement.

\section{Collection of kidney samples}

At the end of experiment, the animals were anesthetized by high dose of sodium thiopental. then midline laparotomy was done and the kidney quickly removed and bisected into two equivalent parts, one half was stored in neutral buffered formalin $10 \%$ for histopathological examination and the second half was quickly placed in liquid nitrogen in RNAse free tubes for PCR of HO- 1 and measurement of TGF- $\beta 1$ and markers of redox state (MDA, SOD, CAT and GSH).

\section{Assay of redox state markers (MDA, SOD, NO, catalase and SOD) in renal tissues}

Details of homogenization of kidney tissues and measurement of malondialdehyde (MDA) (marker of lipid peroxidations), superoxide dismutase (SOD) and catalase (antioxidant enzymes), reduced glutathione (GSH) and nitric oxide (NO) in kidney tissues by using commercial available kits (Bio-Diagnostics, Dokki, Giza, Egypt) are described in our previous work (Shokeir et al. 2014).

\section{Assessment of mRNA of HO-1 expression in kidney tissue by real time $q P C R$}

Details of homogenization of kidney tissues and real time PCR methodology for HO-1 are described in our previous work (Shokeir et al. 2014). The sequence of the primer of tested genes as follow HO-1: forward, 5'-TCACCTTCCCGAGCATCGAC-3'; reverse, 5'-TCACCCTGTGCTTGACCTCG-3'; and GAPDH forward: 5'-CCA GGG CTG CCT TCT CTT GT-3', reverse: 5'-CTG TGC CGT TGA 
ACT TGC CG-3'. Analysis of data was done using ABI prism 7000 by equation $2^{-\Delta \Delta c t}$ (Livak and Schmittgen 2001).

\section{Measurement of TGF- $\beta 1$ by flow cytometry in blood and kidney tissues}

\section{Blood and kidney tissues cell suspensions preparation}

Lymphocytes were collected from EDTA-treated blood samples as follow: the blood sample was diluted with same volume of PBS ( $\mathrm{pH} 7.4$ ), then the diluted blood was added to the same volume of lymphoflot (ficol) in $20 \mathrm{cc}$ centrifuge tube. Then, centrifugation for $20 \mathrm{~min}$ at $1500 \mathrm{rpm}$ was done. The lymphocytes were collected in white band at the boundary between plasma and lymphoflot. The band of cells were carefully pipetted into another centrifuge tube and complete with PBS, then mixed together and centrifuged for $10 \mathrm{~min}$ at $1800 \mathrm{rpm}$. Discarding the supernatant and resuspending the lymphocyte sediment and filling up with PBS and then centrifugation again for $10 \mathrm{~min}$ at $1200 \mathrm{rpm}$ were done. Finally, discarding the supernatant and fixing the lymphocytes with $1 \mathrm{ml}$ ice cold absolute alcohol was done and the preparation was preserved at $4^{\circ} \mathrm{C}$ until investigation. Regarding kidney tissues, the fresh kidney tissue was sent to laboratory in isotonic saline and prepared according to Tribukait et al. (1975). Also, the cell suspension was fixed in ice-cold $96-100 \%$ ethanol in approximately $1 \mathrm{ml}$ for each sample and preserved at $4^{\circ} \mathrm{C}$ until investigation.

\section{Flow cytometric analysis}

After $12 \mathrm{~h}$ cells fixation, the specimen was centrifuged again and the excess of ethanol was discarded (Vindelov 1977). Then, the cell suspension was placed in citrate buffer and $200 \mu \mathrm{l}$ of the preparation was mixed with propidium iodide in a $15 \mathrm{ml}$ Falcon tube and filtered through a $30 \mu \mathrm{m}$ pore diameter nylon mesh filter and the nuclear clumps was collected in a $5 \mathrm{ml}$ Falcon tube. The flow cytometery run was done within $1 \mathrm{~h}$ of propidium iodide addition. Analysis of data was done by MODFIT DNA analysis program (verity software house, Inc. P.O. Box 247, Topsham, ME 04086 USA, version: 2.0 power Mac with $131072 \mathrm{~KB}$ Registration \#: 42000960827-16193213). The software assessed DNA ploidy (diploid cycle\% and aneuploid cycle\%) and cell cycle analysis, which computed the coefficient of variation $(\mathrm{CV})$ around the G0/G1 peak "apoptosis percentage" DNA index (DI) and the rate in each stage of cells (G0/G1, S and G2/M) of the DNA cell cycle for each sample. We used FACS calibar flow cytometer in Mansoura Children Hospital (Becton Dickinson, Sunnyvale, CA, USA) which is prepared with a compact air cooked low power $15 \mathrm{t} \mathrm{mW}$ Argon ion laser beam (488 nm). The average number of calculated nuclei per specimen was 20.000 and the number of nuclei checked was $120 /$ s.

\section{Histopathological examination of kidney tissues}

Paraffin blocks were prepared from formalin-fixed kidneys and sections of 3- $\mu \mathrm{m}$ thickness were processed and stained with haemtoxylin \& eosin and observed blindly by Olympus light microscope (Olympus BX51, Tokyo, Japan). Ischemic tubular injury was scored (scores from 0 to 4 ) according to the score established by Solez et al. (1974), as follows: score 0, no damage in renal tubules; score 1, patchy isolated tubular necrosis; score 2, tubular necrosis affecting less than 25\%; score 3, tubular necrosis between $25 \%$ and $50 \%$; score 4 , tubular necrosis affecting more than $50 \%$ of renal tubules.

\section{Statistical analysis}

Statistical analysis was done by using SPSS version 16.0. To test statistical significance among groups, one way ANOVA test followed by Tukey's posthoc test were used. It was considered significant if $p<0.05$.

\section{Results}

\section{Kidney functions (serum creatinine and urea)}

Serum creatinine and urea levels were significantly higher in ischemic group than sham group at $24 \mathrm{~h}$ and $48 \mathrm{~h}(p<0.05)$. Also, their levels were significantly lower in CoPP-treated groups than ischemic group at the same time interval $(p<$ 0.001 ). At day 7 , serum creatinine showed no statistical significant difference among all groups; while serum urea level was significantly higher in ischemic group than sham and CoPP-treated groups $(p<0.05)$. Moreover, serum urea showed significant higher levels in CoPP-after group than CoPPbefore group at all time intervals $(p<0.01)$, while creatinine showed no statistical significant difference between the two groups (Table 1).

\section{Markers of oxidative stress (MDA, GSH and SOD, CAT) in kidney tissues}

In kidney tissues, MDA concentration was significantly higher in ischemic group than sham group, while SOD, catalase and GSH levels were significantly lower in ischemic group than sham group at all time intervals $(p<0.05)$. On the other hand, MDA level became significantly lower in CoPP-treated groups than ischemic group, while SOD and GSH levels became significantly higher in CoPP-treated groups than ischemic group at all time intervals $(p<0.05)$. CAT exhibited no statistical significant difference in CoPPtreated groups, while it was significantly higher in CoPP-after group than in ischemic and CoPP-before groups at different time intervals, $(p<0.05)$ (Table 2$)$. 
Table 1. Effects of CoPP on renal functions (serum creatinine and urea)

\begin{tabular}{clcc}
\hline $\begin{array}{c}\text { Time of } \\
\text { sacrifice }\end{array}$ & Group & $\begin{array}{c}\text { Serum creatinine } \\
(\mathrm{mg} / \mathrm{dl})\end{array}$ & $\begin{array}{c}\text { Serum urea } \\
(\mathrm{mg} / \mathrm{dl})\end{array}$ \\
\hline \multirow{4}{*}{$24 \mathrm{~h}$} & Sham & $0.399 \pm 0.142$ & $35.16 \pm 4.24$ \\
& Ischemic & $1.097 \pm 0.037^{*}$ & $187.83 \pm 10.82^{*}$ \\
& CoPP-before & $0.435 \pm 0.009^{\#}$ & $50.58 \pm 7.28^{\#^{*}}$ \\
& CoPP-after & $0.511 \pm 0.013^{\#}$ & $67.72 \pm 11.20^{\#^{*}}$ \\
\hline \multirow{4}{*}{$48 \mathrm{~h}$} & Sham & $0.572 \pm 0.065$ & $32.53 \pm 3.23$ \\
& Ischemic & $1.33 \pm 0.043^{*}$ & $150.36 \pm 11.87^{*}$ \\
& CoPP-before & $0.851 \pm 0.046^{\#}$ & $46.10 \pm 6.74^{\#^{*}}$ \\
& CoPP-after & $0.820 \pm 0.015^{\#}$ & $59.93 \pm 8.27^{\#^{*}}$ \\
\hline \multirow{4}{*}{7 day } & Sham & $0.391 \pm 0.037$ & $22.78 \pm 3.21$ \\
& Ischemic & $0.438 \pm 0.01$ & $81.20 \pm 11.36^{*}$ \\
& CoPP-before & $0.553 \pm 0.026$ & $38.47 \pm 3.59^{\#^{*}}$ \\
& CoPP-after & $0.521 \pm 0.019^{\#}$ & $56.00 \pm 5.50^{\#^{*}}$ \\
\hline
\end{tabular}

All data were expressed as mean \pm SE; $n=6$ rats in each group; one-way ANOVA with Tukey's post hoc test; ${ }^{*}$ significant $v s$. sham group, " significant $v s$. ischemic group, ${ }^{\ddagger}$ significant $v$ s. CoPP-before group ( $p \leq 0.05$ is considered significant).

\section{NO in kidney tissues}

Renal NO level was statistical significantly lower in ischemic, CoPP-treated groups than sham group at all time intervals $(p<0.05)$. Also, renal NO level became significantly higher in CoPP-treated groups than ischemic group at $24 \mathrm{~h}, 48 \mathrm{~h}$ and day $7(p<0.05)$ (Fig. 1).

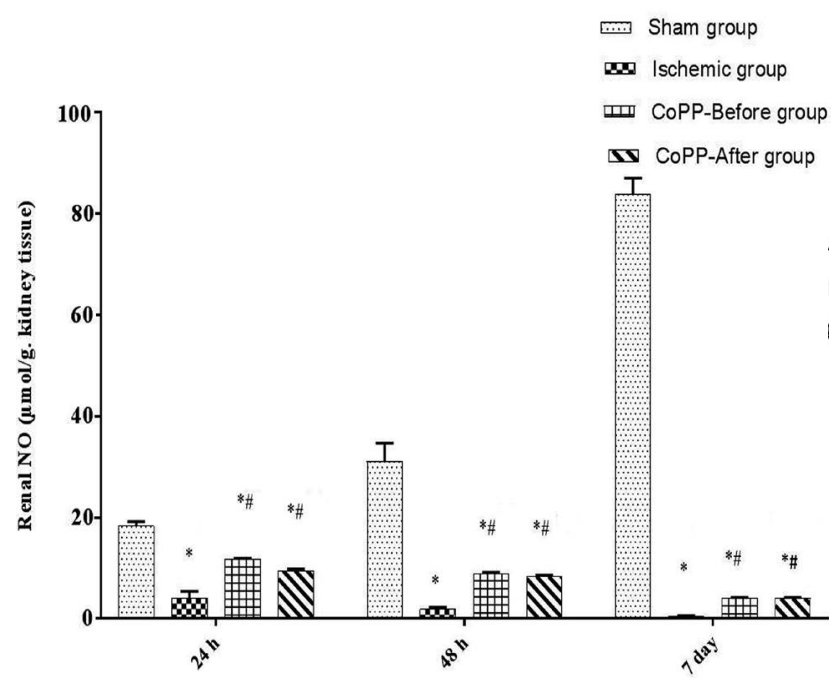

Figure 1. Effects of CoPP on concentration of nitric oxide in kidney tissues. ${ }^{*}$ Significant $v s$. sham group; ${ }^{\#}$ significant $v s$. ischemic group; $p \leq 0.05$ is considered significant.

\section{Expression of HO-1 in kidney tissues}

Renal mRNA of HO-1 showed significant increase in ischemic and CoPP-treated groups compared to sham group at $24 \mathrm{~h}, 48 \mathrm{~h}(p<0.05)$. Moreover, renal mRNA of HO- 1 was significantly higher in CoPP-treated groups than ischemic group at $24 \mathrm{~h}, 48 \mathrm{~h}$ and day $7(p<0.05)$ (Fig. 2).

\section{TGF- $\beta 1$ levels in serum and kidney tissues}

TGF- $\beta 1$ levels in serum and kidney tissues were significantly higher in ischemic group than sham group at $24 \mathrm{~h}, 48 \mathrm{~h}$ and

Table 2. Effects of CoPP on markers of oxidative stress (MDA, SOD, CAT and GSH) in kidney tissues

\begin{tabular}{|c|c|c|c|c|c|}
\hline $\begin{array}{l}\text { Time of } \\
\text { sacrifice }\end{array}$ & Group & $\begin{array}{c}\text { MDA } \\
\text { (nmol/g kidney tissue) }\end{array}$ & $\begin{array}{c}\text { SOD } \\
\text { (U/g kidney tissue) }\end{array}$ & $\begin{array}{c}\text { Catalase } \\
\text { (U/g kidney tissue) }\end{array}$ & $\begin{array}{c}\text { GSH } \\
\text { (mmol/g kidney tissue) }\end{array}$ \\
\hline \multirow{4}{*}{$24 \mathrm{~h}$} & Sham & $6.25 \pm 0.14$ & $229.70 \pm 27.46$ & $2.04 \pm 0.017$ & $12.23 \pm 1.02$ \\
\hline & Ischemic & $60.007 \pm 3.13^{*}$ & $186.78 \pm 15.71^{*}$ & $1.72 \pm 0.009^{*}$ & $8.93 \pm 1.15^{*}$ \\
\hline & CoPP-before & $10.03 \pm 2.28^{\#}$ & $462.58 \pm 54.48^{* \#}$ & $1.80 \pm 0.006$ & $12.98 \pm 2.09^{\#}$ \\
\hline & CoPP-after & $10 . .19 \pm 3.5^{\#^{*}}$ & $290.67 \pm 32.6^{* \# \neq}$ & $2.76 \pm 0.16^{\# \ddagger}$ & $13.15 \pm 1.4^{\star \#}$ \\
\hline \multirow{4}{*}{$48 \mathrm{~h}$} & Sham & $5.54 \pm 1.07$ & $188.40 \pm 34.13$ & $1.68 \pm 0.09$ & $11.47 \pm 2.64$ \\
\hline & Ischemic & $50.61 \pm 7.68^{\star}$ & $328.83 \pm 27.07^{\star}$ & $1.91 \pm 0.018^{*}$ & $7.75 \pm 1.05^{*}$ \\
\hline & CoPP-before & $9.13 \pm 1.095^{\#^{*}}$ & $527.29 \pm 29.49^{* \#}$ & $1.78 \pm 0.009$ & $16.37 \pm 2.29^{* \#}$ \\
\hline & CoPP-after & $11.84 \pm 2.15^{\#^{*}}$ & $614.37 \pm 45.70^{\star \# \neq}$ & $2.64 \pm 0.011^{\star \# \pm}$ & $15.50 \pm 1.5^{\star \#}$ \\
\hline \multirow{4}{*}{7 day } & Sham & $1.71 \pm 0.22$ & $93.32 \pm 18.43$ & $1.28 \pm 0.009$ & $11.47 \pm 2.64$ \\
\hline & Ischemic & $37.49 \pm 2.31^{\star}$ & $468.17 \pm 46.53^{*}$ & $2.12 \pm 0.012^{*}$ & $7.01 \pm 0.38^{*}$ \\
\hline & CoPP-before & $8.40 \pm 1.22^{\#^{\star}}$ & $620.95 \pm 35.29^{* \#}$ & $1.73 \pm 0.006$ & $23.50 \pm 2.44^{\star \#}$ \\
\hline & CoPP-after & $11.30 \pm 2.5^{\#^{*} \ddagger}$ & $841.08 \pm 51.8^{* \# \ddagger}$ & $2.34 \pm 0.019^{*}$ & $21.32 \pm 2.4^{\star \#}$ \\
\hline
\end{tabular}

All data were expressed as mean \pm SE; $n=6$ rats in each group; one-way ANOVA with Tukey's post hoc test; ${ }^{*}$ significant $v s$. sham group,

${ }^{\#}$ significant $v s$. ischemic group, ${ }^{\ddagger}$ significant $v s$. CoPP-before group ( $p \leq 0.05$ is considered significant). 
A

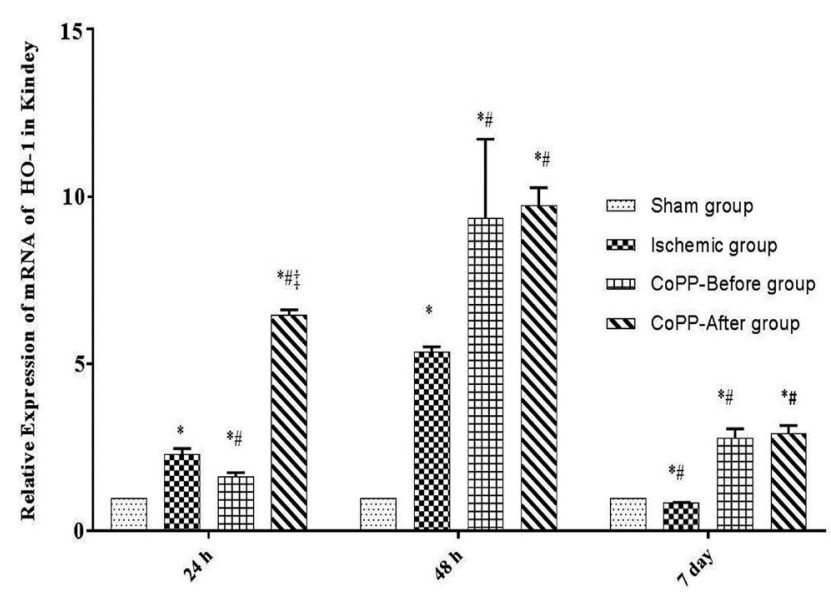

C

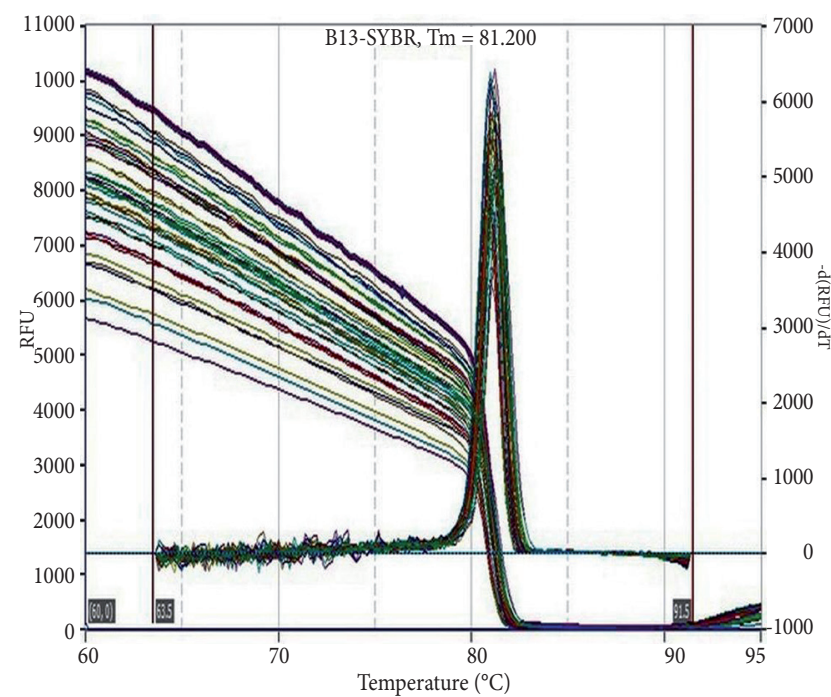

E

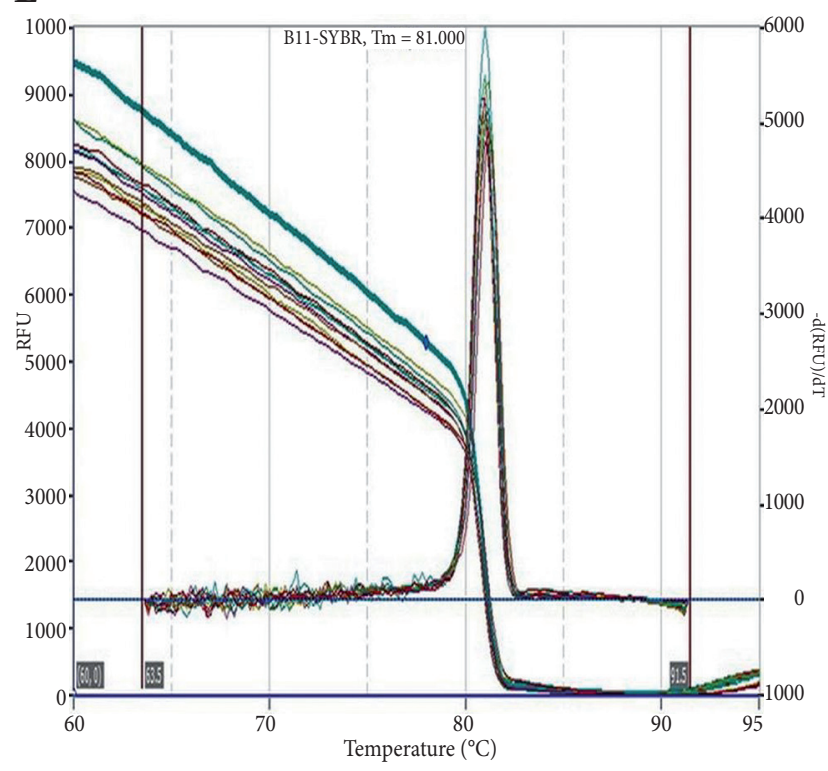

B

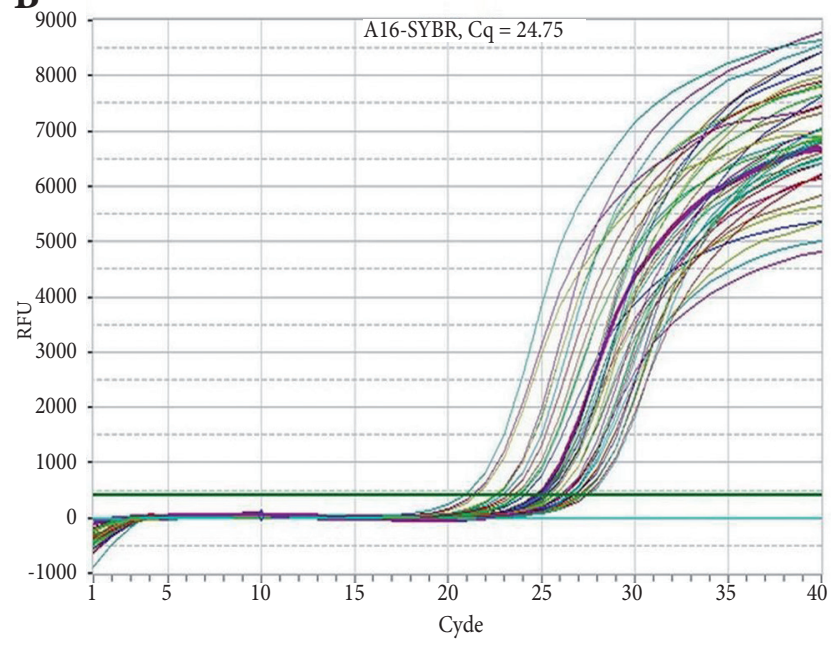

D

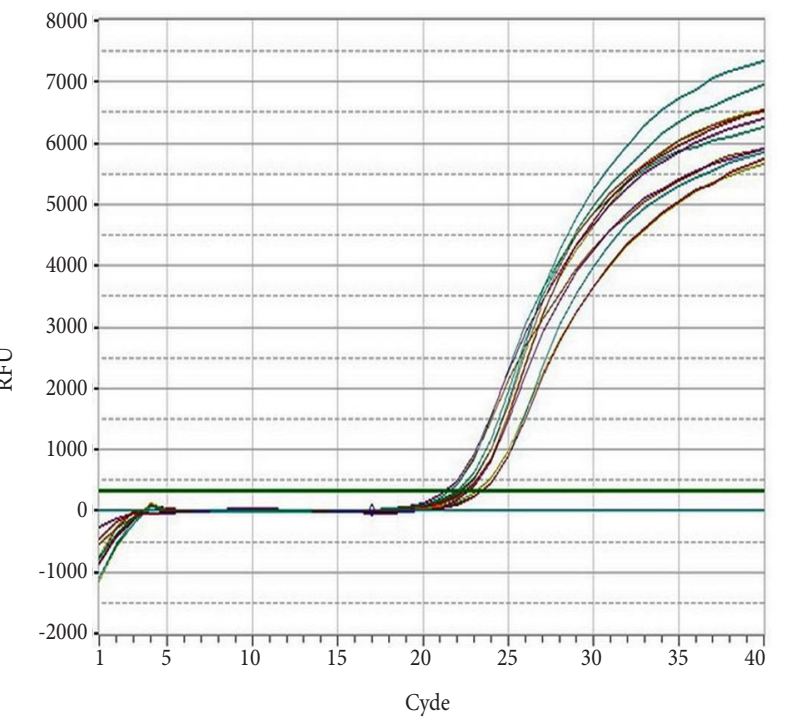

Figure 2. PCR study of the heme oxygenase 1 (HO-1) mRNA. A. The relative expression of mRNA of HO-1 in kidney tissues in different groups. B. PCR amplification curve. C. PCR melting curve from $1-14$ cycles. D. PCR curves of amplification. E. Melting of HO- 1 from 15 to 18 cycles. ${ }^{*}$ Significant $v s$. sham group; ${ }^{*}$ significant $v$ s. ischemic group; ${ }^{\ddagger}$ significant $v s$. CoPP-before group; $p \leq$ 0.05 is considered significant. 

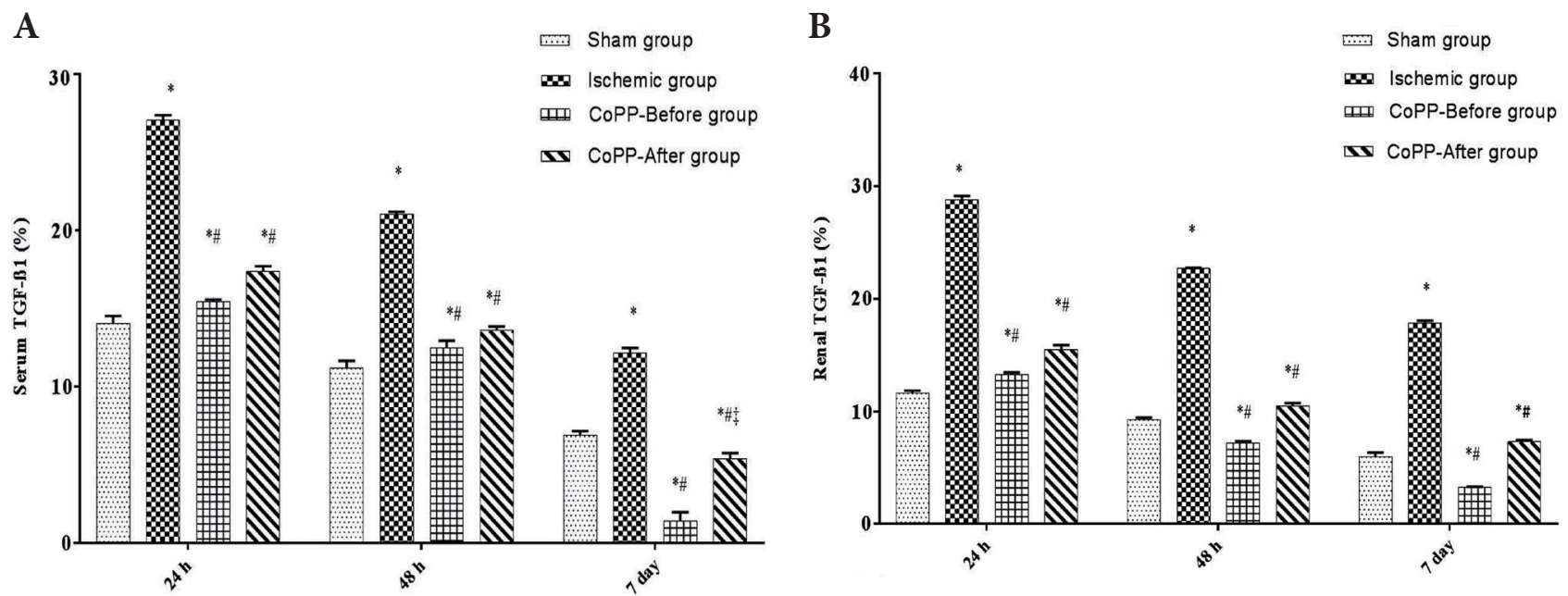

Figure 3. Effects of CoPP on TGF- $\beta 1$ levels in serum and kidney tissues in different groups. ${ }^{*}$ Significant $v s$. sham group; ${ }^{\#}$ significant $v s$. ischemic group; $p \leq 0.05$ is considered significant.

day 7 ( $p<0.05)$. CoPP-before and after groups showed significant attenuation in serum and renal levels of TGF- $\beta 1$ compared to ischemic group at $24 \mathrm{~h}, 48 \mathrm{~h}$ and day $7(p<0.05)$ (Fig. 3).

\section{Histopathology of kidney tissues}

Tubulointerstitial damage scores were significantly higher in ischemic, CoPP-treated groups than in sham groups $(p<0.05)$ and were significantly lower in CoPP-treated groups than in ischemic group $(p<0.05)$ (Fig. $4 \mathrm{M})$. The kidneys taken from sham group rats exhibited normal kidney structure i.e. normal morphology of renal tubules (PCT, DCT and CD) and normal glomerular architecture at various times (Fig. 4A-C). While, kidneys taken from ischemic group exhibited severe tubular damage in the form of tubular epithelial cell desquamation, necrosis and hyaline tubular casts and interstitial congestion
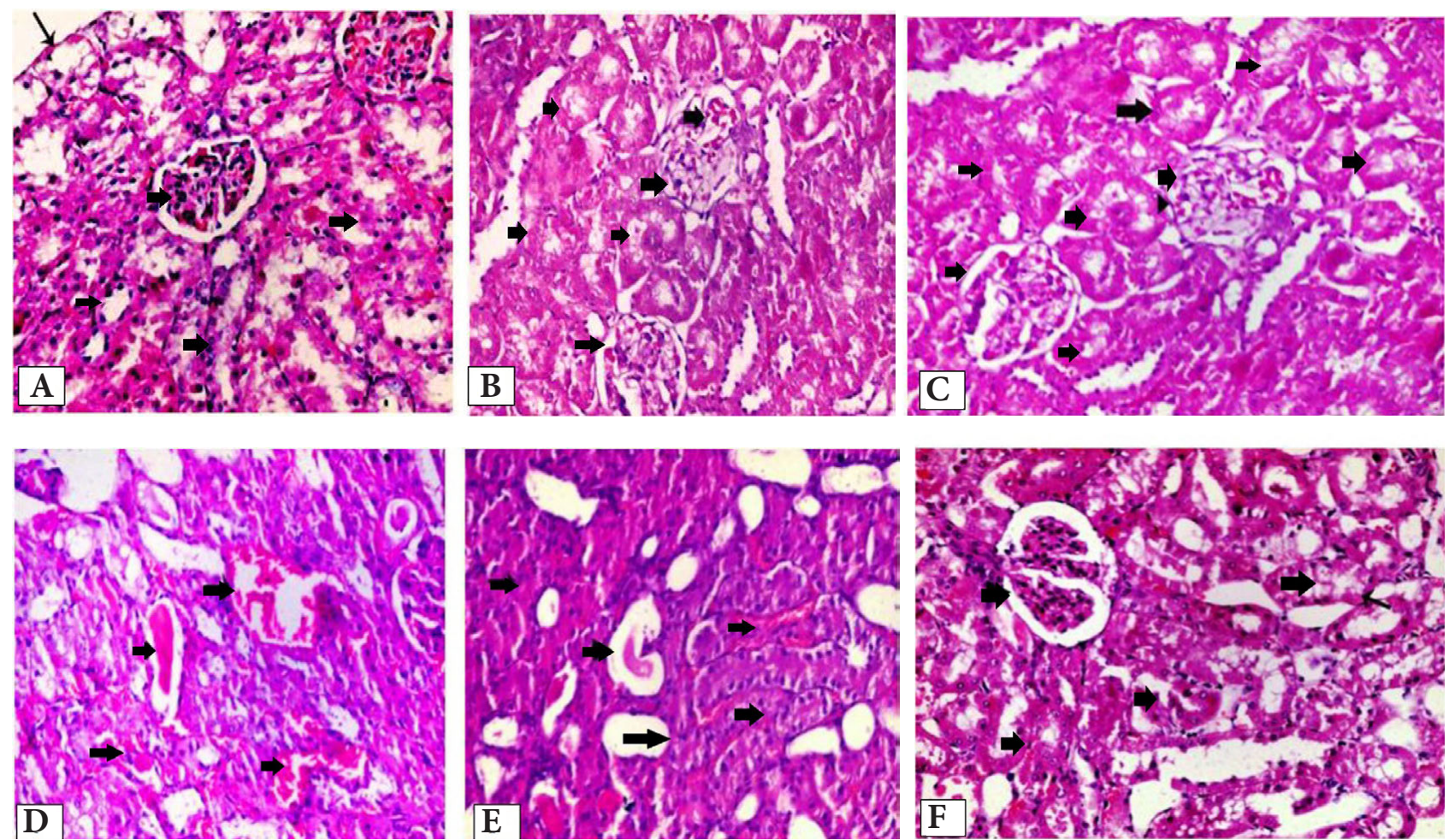

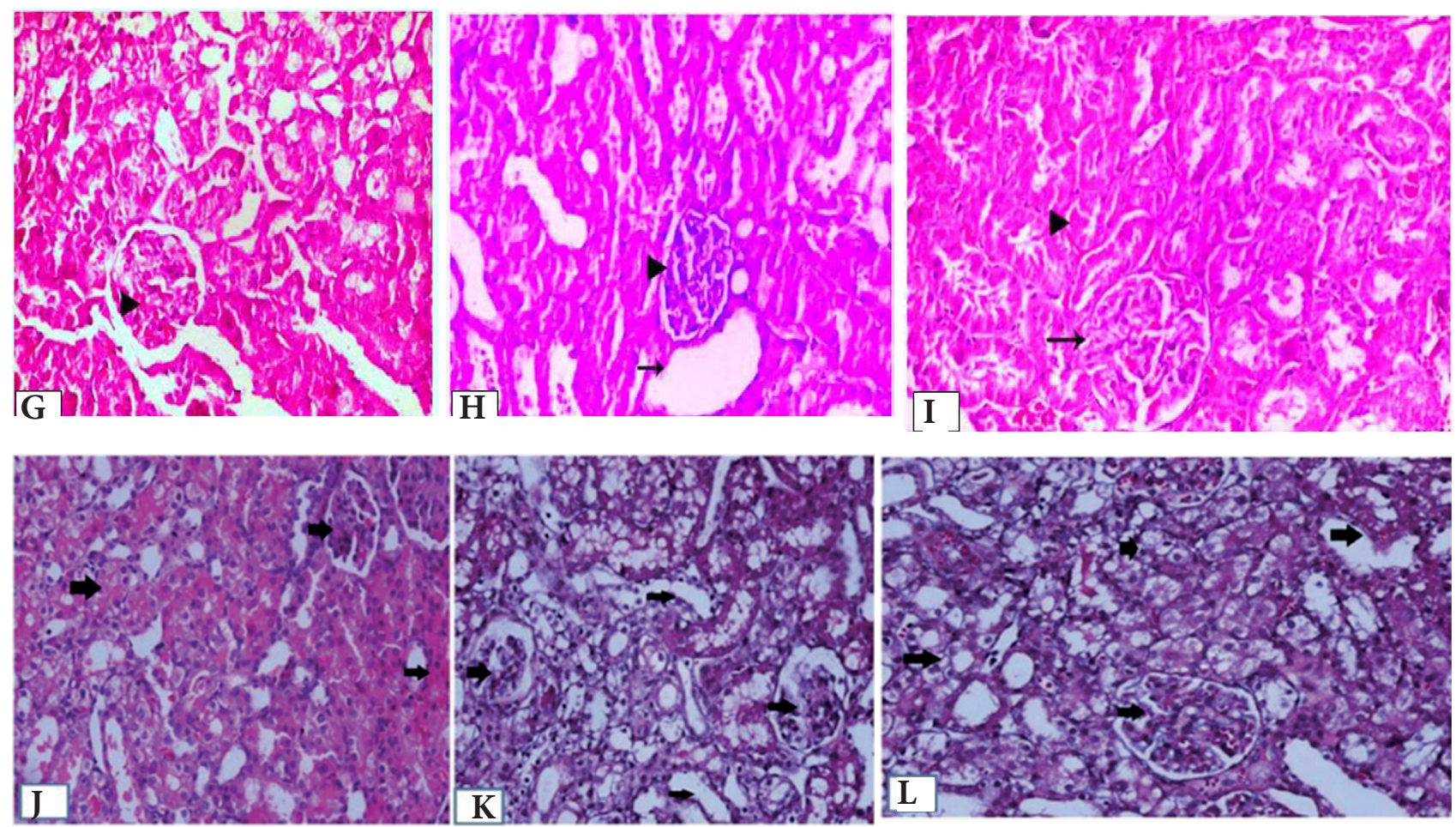

4Figure 4. A. Normal renal glomeruli (arrow head) and normal renal tubules (arrow) at $24 \mathrm{~h}$; B. Normal renal architecture with mild congestion in glomerular capillaries (arrow) at $48 \mathrm{~h}$; C. Normal renal glomeruli (arrow head) and normal renal tubules (arrow) at day 7 (H\&E, 400×). Kidney specimens from ischemic group: D. Necrosis and desquamation of renal tubular epithelium with formation of hyaline cast in the lumen of renal tubules (arrow head), in addition severe congestion and hemorrhage in interstitial tissue (arrow) at $24 \mathrm{~h}$. E. Cloudy swelling (arrow)and cystic dilatation of renal tubules (arrow head) with presence esinophilic hyaline cast in its lumen at 48 h. F. Normal renal glomeruli (arrow head) and normal renal tubules (arrow) at day 7 (H\&E, 400×). Kidney specimems from CoPP-before group: G. Normal renal architecture with degeneration of renal tubules (arrow) at $24 \mathrm{~h}$. H. Cystic dilatation of renal tubules with flattening of renal tubular epithelium (arrow), and normal renal glomeruli (arrow head). I. Normal renal glomeruli (arrow) and $\mathbf{M}$

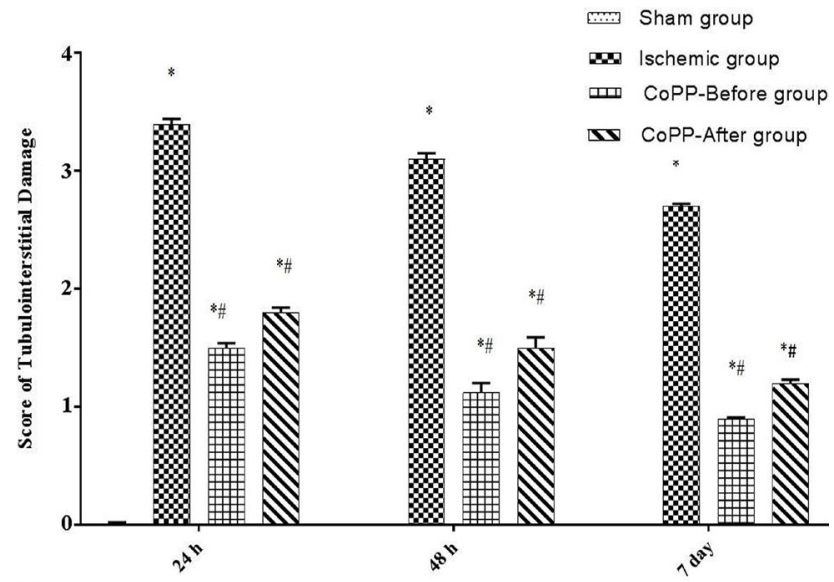
normal renal tubules with normal lining tubular epithelium (arrow head) at day 7 (H\&E, 400×). Kidney specimens from CoPP-after group: J. Normal renal architecture with minimal degeneration of renal tubules (arrow) at 24 h; Normal glomerular structure of the kidney and renal tubules at $48 \mathrm{~h}(\mathbf{K})$ and at day 7 (L) (arrows) (H\&E, 400×). M. Tubulointerstitial damage score in different groups. ${ }^{*}$ Significant $v$ s. sham group, ${ }^{\#}$ significant $v s$. ischemic group; $p \leq 0.05$ is considered significant. Kidney specimens from sham group.

and hemorrhage (Fig. 4D-F). On the other hand, kidneys taken from CoPP-before and after groups exhibited normal kidney structure with minimal tubular epithelial cells degeneration, cystic dilatation of renal tubules with flattening of renal tubular epithelium and normal renal glomerular structure (Fig. 4G-L).

\section{Discussion}

The current study confirmed that renal I/R injury caused significant damage to kidney morphology and functions and enhancement of oxidative stress (high MDA and HO-1 with 
low CAT, SOD and GSH levels) and inflammatory reaction (high TGF- $\beta 1$ and NO) in kidney tissues. Also, upregulation of HO- 1 by CoPP either before or after renal ischemia caused significant improvement in kidney functions and morphology, oxidative stress (low MDA with high CAT, SOD and GSH levels) and inflammatory reaction (low TGF- $\beta 1$ and $\mathrm{NO}$ ) in kidney tissues.

In the current study, we demonstrated that 45 -min ischemia caused significant deterioration in kidney functions as evidenced by significant increase in serum creatinine and urea in ischemic group. Also, renal ischemia caused severe renal tubular and glomerular damage in histopathological examination of kidney tissues. Similar findings are previously reported by our research group and others investigators (Chatterjee et al. 2002; Singh et al. 2004; Chander and Chopra 2006; Shokeir et al. 2014; Hussein et al. 2016). These findings confirmed that 45 -min renal ischemia is sufficient to produce functional and morphological changes in kidney without high losses of rats (Weight et al. 1998). Previous studies reported that the kidney damage and rat mortality become more significant in 60 and $90 \mathrm{~min}$ ischaemia and the mortality after the third day in 90-min ischaemia model is about $100 \%$ (Mehta et al. 2002).

Also, we demonstrated in current study enhanced redox state in kidney tissues of ischemic group in the form of significant increase in MDA concentration (marker of lipid peroxidations) and significant reduction in SOD, catalase and GSH. These findings are in line with those reported investigators (Singh and Chopra 2004; Singh et al. 2004; Chander and Chopra 2006; Shokeir et al. 2014). It has been reported that the vascular endothelial cells (having hypoxanthine/ xanthine oxidase system) and activated neutrophils are the main sources for ROS during I/R injury (Yoshioka and Ichikawa 1989). These ROS contribute to the glomerular damage during renal $\mathrm{I} / \mathrm{R}$ injury by either enhancing the secretion of vasoactive mediators such as endothelins, thromboxane A2 and angiotensin II (Pararajasingam et al. 2000) or inhibiting the actions of NO (Cristol et al. 1993). These mediators cause renal vasoconstriction and reduce the glomerular capillary ultrafiltration coefficient leading to reduction in the glomerular filtration rate (Singh et al. 2004; Chander and Chopra 2006). Furthermore, oxidative stress caused damage of renal tubular cells by loss of plasma membrane and mitochondrial membrane integrity (Schnackenberg 2002). Furthermore, the ROS causes extreme damage of DNA and mitochondrial membrane integrity causing renal tubular cell apoptosis through activation of mitochondrial pathway ( $\mathrm{Wu}$ and Cederbaum 2003).

$\mathrm{NO}$ is formed in our body from l-arginine by nitric oxide synthases. During renal IR injury, NO may play a beneficial role by keeping renal blood flow, stopping platelet plugging and stopping neutrophil aggregation (Pinsky et al. 1994) and may have damaging role by conjoining with the superoxide radical to form peroxynitrite $\left(\mathrm{OONO}^{-}\right)$which was supposed to be responsible for the shedding of renal tubular cells in ischemic segments (Wangsiripaisan et al. 1999). The current study demonstrated significant increase in renal $\mathrm{NO}$ in ischemic group which may be compensatory response to keep renal blood flow during ischemic injury. It has been demonstrated that inhibition of NO synthesis by NOS inhibitors such as L-NAME was associated with severe and prolonged vasoconstriction after renal ischemia (Tome et al. 1994; Weight et al. 1999, Pararajasingam et al. 2000; Saito and Miyagawa 2000) and severe damage of kidney morphology and functions (Rhoden et al. 2002; Mahmoud et al. 2007).

TGF- $\beta 1$ is an inflammatory cytokine which has many biological effects such as induction of cell apoptosis, differentiation, and proliferation (Siegel and Massague 2003) and epithelial-mesenchymal transformation (Heldin et al. 2009). Basile et al. (1996) demonstrated significant increase in TGF- $\beta 1$ expression to in regenerating renal tubules after ischemic injury to 1.5 -fold at $12 \mathrm{~h}$ and 3.6 -fold at $24 \mathrm{~h}$, and rests higher for 14 days. Also, Lario et al. 2003 demonstrated higher expression of it in renal biopsies of kidney transplants from cold ischemic donors or at 5 days post-transplantation. In the current study, TGF- $\beta 1$ was significantly increased in serum and kidney tissues of ischemic group at $24 \mathrm{~h}$ and $48 \mathrm{~h}$ after ischemia. Several studies demonstrated harmful effects for TGF- $\beta 1$. Miyajima et al. (2000) demonstrated that the use of anti- TGF- $\beta 1$ antibody was associated with significant increase in tubular proliferation and attenuation of tubular apoptosis in the kidneys and Miyajima et al. (2001) demonstrated that reduction of TGF- $\beta 1$ by tranilast treatment in unilateral ureteral obstruction was associated with significant decrease in renal tubular apoptosis. Also, Ling et al. (2003) reported that inhibition of TGF- $\beta 1$ prevent renal tubular epithelial cells apoptosis in cyclosporine-A (CsA)mediated nephrotoxicity. On other hand, other studies demonstrated beneficial effects for TGF- $\beta 1$. Lee et al. (2007) demonstrated that TGF- $\beta 1$ mediates the renoprotective effects of volatile anesthetics in $\mathrm{H}_{2} \mathrm{O}_{2}$-induced apoptosis in HK-2 cells and Lee et al. (2004) demonstrated that TGF- $\beta 1$ reduced the necrosis and inflammation in renal IR injury.

One of the main aims of the current study was to explore the role of HO-1 in renal ischemia. It has been shown that ischemic injury in many organs such as heart caused acute HO-1 upregulation (Masini et al. 2003; Giannini et al. 2005; Lakkisto et al. 2009; Yeh et al. 2009). We demonstrated, in the current study, upregulation of HO-1 in ischemic kidney tissues suggesting a role for HO-1 in renal I/R injury. Also, chronic induction of HO-1 exhibited protective effects in a rat model of hepatic ischemic injury (Fang et al. 2011) and controlled renal hemodynamics and renal excretory function in ischemic kidney diseases (Ferenbach et al. 2010). Additionally, $\mathrm{HO}-1$ possesses antioxidant and anti-inflammatory properties that are essential for NO preservation (Liu et al. 2015). 
The last and main objective of the current study was to examine the effects of a potent HO-1 inducer (cobalt protoporphyrin X, $20 \mathrm{mg} / \mathrm{kg}$ i.p) on renal I/R injury. In the current study, we found that CoPP administration either before or after renal ischemia caused significant enhancement in kidney functions (serum creatinine and urea) and kidney morphology suggesting renoprotective effects for CoPP against renal I/R injury when given before or after renal ischemia. Moreover, we reported in the present study significant attenuation of redox state in the form of reduction of MDA and upregulation of SOD, GSH and CAT in kidney tissues of CoPP-treated groups suggesting antioxidant effects for CoPP in renal IR injury. Also, the levels of pro-inflammatory cytokine TGF- $\beta 1$ in serum and kidney tissues were significantly attenuated in CoPPtreated groups (before and after-CoPP groups) suggesting anti-inflammatory action for CoPP in renal I/R injury. Moreover, CoPP enhanced the levels of NO in kidney tissues suggesting improvement of vascular endothelial dysfunctions.

Previous studies investigated the mechanisms underlying the protective effects of CoPP in several animal models. Liu et al. (2015) showed that HO-1 upregulation by cobalt protoporphyrin reduced the degree of microalbuminuria by ameliorating endothelial dysfunctions and regulating the glomerular VEGF-NO axis in obese rats. Also, Abraham et al. (2002) showed that pretreatment with CoPP reduced the levels of cytochrome P450-derived arachidonic acid metabolite, 20 -HETE, a potent vasoconstrictor, by $65 \%$ in renal tissue in rats with spontaneous hypertension. In kidney transplantation, Bédard et al. (2005) reported that treatment with CoPP (at a dose of $0.5 \mathrm{mg} / \mathrm{kg}$ at days $-5,0,+5$ ) attenuated the chronic graft rejection in renal allograft recipients' rats by improving the vascular dysfunctions in the form of HO-1 upregulation and endothelin-1 downregulation in transplanted kidney tissues. Wagner et al. (2003) found that pretreatment of CoPP upregulated HO-1, preserved graft function and attenuated apoptosis after cold preservation. In ureteral obstruction, pretreatment with CoPP (at a dose of 15 or $50 \mathrm{mg} / \mathrm{kg}$, subcutaneously) 6 days and 1 day before unilateral ureteral obstruction caused significant improvement in kidney function and morphology which was associated with upregulation of $\mathrm{HO}-1$ and inhibition of $\mathrm{T}$ cell infiltration in kidney tissues (Iwai et al. 2008).

The antioxidant effects of CoPP treatment was demonstrated in previous studies. In diabetic nephropathy, several studies reported the antioxidant and anti-inflammatory effects for CoPP treatment and HO-1 upregulation (Goodman et al. 2006; Lee et al. 2009; Elmarakby et al. 2012). This antioxidant effects for HO-1 might be due to reduction of the activity of NADPH oxidase (Datla et al. 2007; Li et al. 2008; Elmarakby et al. 2012). Also, it has been reported that, $\mathrm{HO}-1$ upregulation attenuated nuclear factor- $\mathrm{\kappa B}$-induced inflammation in kidney tissues (Elmarakby et al. 2012; Ndisang and Jadhav 2014; Liu et al. 2015). Finally, previous studies reported HO-1-independent mechanisms for the protective effects of $\mathrm{CoPP}$ such as induction of $\mathrm{P} 2 \mathrm{X} 7$ receptor activation, COX-2 expression and PIAS1 breakdown which is controlled by PI3K, Akt, and glycogen synthase kinase $3 \alpha / \beta($ GSK3 $\alpha / \beta)$ signaling pathways in microglial cells (Lin et al. 2016).

\section{Conclusion}

CoPP treatment before or after renal ischemia caused upregulation of HO-1 in kidney tissues and protected kidney function and morphology against renal I/R injury. This might be due to improvement of oxidative stress and attenuation of inflammatory cytokines in kidney tissues.

\section{References}

Abraham NG, Botros FT, Rezzani R, Rodella L, Bianchi R, Goodman AI (2002): Differential effect of cobalt protoporphyrin on distributions of heme oxygenase in renal structure and on blood pressure in SHR. Cell Mol. Biol. (Noisy-le-grand). 48, 895-902

Basile DP, Rovak JM, Martin DR, Hammerman MR (1996): Increased transforming growth factor-beta 1 expression in regenerating rat renal tubules following ischemic injury. Am. J. Physiol. 270, F500-509 https://doi.org/10.1152/ajprenal.1996.270.3.F500

Bédard EL, Jiang J, Parry N, Wang H, Liu W, Garcia B, Kim P, Chakrabarti S, Buelow R, Zhong R (2005): Peritransplant treatment with cobalt protoporphyrin attenuates chronic renal allograft rejection. Transpl. Int. 18, 341-349 https://doi.org/10.1111/j.1432-2277.2004.00062.x

Chander V, Chopra K (2006): Protective effect of nitric oxide pathway in resveratrol renal ischemia-reperfusion injury in rats. Arch. Med. Res. 37, 19-26 https://doi.org/10.1016/j.arcmed.2005.05.018

Chatterjee PK, Patel NS, Kvale EO, Cuzzocrea S, Brown PA, Stewart KN, Mota-Filipe H, Thiemermann C (2002): Inhibition of inducible nitric oxide synthase reduces renal ischemia/reperfusion injury. Kidney Int. 61, 862-871 https://doi.org/10.1046/j.1523-1755.2002.00234.x

Cristol JP, Thiemermann C, Mitchell JA, Walder C, Vane JR (1993): Support of renal blood flow after ischemic -reperfusion injury by endogenous formation of nitric oxide and of cyclooxygenase vasodilator metabolites. Br. J. Pharmacol. 109, 188-194 https://doi.org/10.1111/j.1476-5381.1993.tb13552.x

Datla SR, Dusting GJ, Mori TA, Taylor CJ, Croft KD, Jiang F (2007): Induction of heme oxygenase-1 in vivo suppresses NADPH oxidase-derived oxidative stress. Hypertension 50, 636-642 https://doi.org/10.1161/HYPERTENSIONAHA.107.092296

Elmarakby AA, Faulkner J, Baban B, Saleh MA, Sullivan JC (2012): Induction of hemeoxygenase-1 reduces glomerular injury and 
apoptosis in diabetic spontaneously hypertensive rats. Am. J. Physiol. Renal. Physiol. 302, F791-F800 https://doi.org/10.1152/ajprenal.00472.2011

Fang J, Qin H, Seki T, Nakamura H, Tsukigawa K, Shin T, Maeda H (2011): Therapeutic potential of pegylated hemin for reactive oxygen species-related diseases via induction of heme oxygenase-1: results from a rat hepatic ischemia/reperfusion injury model. J. Pharmacol. Exp. Ther. 339, 779-789 https://doi.org/10.1124/jpet.111.185348

Ferenbach DA, Kluth DC, Hughes J (2010): Hemeoxygenase-1 and renal ischaemia-reperfusion injury. Nephron. Exp. Nephrol. 115, e33-e37 https://doi.org/10.1159/000313828

FuY, Yang MS, Jiang J, Ganesh T, Joe E, Dingledine R (2015): EP2 Receptor Signaling Regulates Microglia Death. Mol. Pharmacol. 88, $161-170$ https://doi.org/10.1124/mol.115.098202

Giannini L, Vannacci A, Fabrizi F, Uliva C, Bani D, Masini E, Mannaioni PF (2005): Protection from cardiac injury by induction of heme oxygenase- 1 and nitric oxide synthase in a focal ischaemia-reperfusion model. Cell Mol. Biol. 51, 393-401

Goodman AI, Chander PN, Rezzani R, Schwartzman ML, Regan RF, Rodella L, Turkseven S, Lianos EA, Dennery PA, Abraham NG (2006): Heme oxygenase-2 deficiency contributes to diabetesmediated increase in superoxide anion and renal dysfunction. J. Am. Soc. Nephrol. 4, 1073-1081 https://doi.org/10.1681/ASN.2004121082

Heldin CH, Landstrom M, Moustakas A (2009): Mechanism of TGF-beta signaling to growth arrest, apoptosis, and epithelial-mesenchymal transition. Curr. Opin. Cell Biol. 21, 166-176 https://doi.org/10.1016/j.ceb.2009.01.021

Hussein AM, Harraz AM, Awadalla A, Barakat N, Khater S, Shokeir AA (2016): Remote limb ischemic preconditioning (rIPC) activates antioxidant and antiapoptotic genes and inhibits proinflammatory cytokine genes in renal ischemia/reperfusion injury. Gen. Physiol. Biophys. 35, 77-86

Iwai T, Kitamoto K, Teramoto K, Machida Y, Tamada S, Yukimura T, Iwao H, Nakatani T, Miura K (2008): Cobalt protoporphyrin attenuates rat obstructive nephropathy: role of cellular infiltration. Urology 72, 432-438 https://doi.org/10.1016/j.urology.2007.11.123

Juhasz B, Varga B, Czompa A, Bak I, Lekli I, Gesztelyi R, Zsuga J, Kemeny- Beke A, Antal M, Szendrei L, Tosaki A (2011): Postischemic cardiac recovery in heme oxygenase-1 transgenic ischemic/reperfused mouse myocardium. J. Cell. Mol. Med. 15, 1973-1982 https://doi.org/10.1111/j.1582-4934.2010.01153.x

Kusmic C, Barsanti C, Matteucci M, Vesentini N, Pelosi G, Abraham NG, LAbbate A (2014): Up-regulation of heme oxygenase-1 after infarct initiation reduces mortality, infarct size and left ventricular remodeling: experimental evidence and proof of concept. J. Transl. Med. 12, 89 https://doi.org/10.1186/1479-5876-12-89

Lakkisto P, Csonka C, Fodor G, Bencsik P, Voipio-Pulkki LM, Ferdinandy P, Pulkki K (2009): The heme oxygenase inducer hemin protects against cardiac dysfunction and ventricular fibrillation in ischaemic/reperfused rat hearts: role of connexin 43. Scand. J. Clin. Lab. Invest. 69, 209-218 https://doi.org/10.1080/00365510802474392

Lakkisto P, Kytö V, Forsten H, Siren JM, Segersvärd H, VoipioPulkki LM, Tikkanen I (2010): Heme oxygenase-1 and carbon monoxide promote neovascularization after myocardial infarction by modulating the expression of HIF-1alpha, SDF-1alpha and VEGF-B. Eur. J. Pharmacol. 635, 156-164 https://doi.org/10.1016/j.ejphar.2010.02.050

Lario S, Mendes D, Bescos M, I-igo P, Campos B, Alvarez R, Alcaraz A, Rivera-Fillat F, Campistol JM (2003): Expression of transforming growth factor-betal and hypoxia-inducible factor-1alpha in an experimental model of kidney transplantation. Transplantation 75, 1647-1654 https://doi.org/10.1097/01.TP.0000063128.86981.B2

Lee HT, Ota-Setlik A, Fu Y, Nasr SH, Emala CW (2004): Differential protective effects of volatile anesthetics against renal ischemiareperfusion injury in vivo. Anesthesiology 6, 1313-1324 https://doi.org/10.1097/00000542-200412000-00011

Lee HT, Kim M, Kim J, Emala CW (2007): TGF-beta1 release by volatile anesthetics mediates protection against renal proximal tubule cell necrosis. Am. J. Nephrol. 27, 416-424 https://doi.org/10.1159/000105124

Lee SC, Han SH, Li JJ, Lee SH, Jung DS, Kwak SJ, Kim SH, Kim DK, Yoo TH, Kim JH, Chang SH, Han DS, Kang SW (2009): Induction of heme oxygenase-1 protects against podocyte apoptosis under diabetic conditions. Kidney International 76, 838-848 https://doi.org/10.1038/ki.2009.286

Li M, Kim DH, Tsenovoy PL, Peterson SJ, Rezzani R, Rodella LF, Aronow WS, Ikehara S, Abraham NG (2008): Treatment of obese diabetic mice with a heme oxygenase inducer reduces visceral and subcutaneous adiposity, increases adiponectin levels, and improves insulin sensitivity and glucose tolerance. Diabetes 57, 1526-1535 https://doi.org/10.2337/db07-1764

Lin HY, Tsai CH, Lin C, Yeh WL, Tsai CF, Chang PC, Wu LH, Lu DY (2016): Cobalt protoporphyrin upregulates cyclooxygenase-2 expression through a heme oxygenase-independent mechanism. Mol. Neurobiol. 53, 4497-4508 https://doi.org/10.1007/s12035-015-9376-y

Ling H, Li X, Jha S, Wang W, Karetskaya L, Pratt B, Ledbetter S (2003): Therapeutic role of TGF-beta-neutralizing antibody in mouse cyclosporin A nephropathy: morphologic improvement associated with functional preservation. J. Am. Soc. Nephrol. 14, 377-388 https://doi.org/10.1097/01.ASN.0000042168.43665.9B

Liu X, Pachori AS, Ward CA, Davis JP, Gnecchi M, Kong D, Zhang L, Murduck J, Yet SF, Perrella MA, Pratt RE, Dzau VJ, Melo LG (2006): Heme oxygenase-1 (HO-1) inhibits postmyocardial infarct remodeling and restores ventricular function. FASEB J. 20, 207-216 https://doi.org/10.1096/fj.05-4435com

Liu X, Simpson JA, Brunt KR, Ward CA, Hall SR, Kinobe RT, Barrette V, Tse MY, Pang SC, Pachori AS, Dzau VJ, Ogunyankin KO, Melo LG (2007): Preemptive heme oxygenase-1 gene delivery reveals reduced mortality and preservation of left ventricular function $1 \mathrm{yr}$ after acute myocardial infarction. Am. J. Physiol. Heart Circ. Physiol. 293, H48-H49 
https://doi.org/10.1152/ajpheart.00741.2006

Liu X, Zang P, Han F, Hou N, Sun X (2015): Renal protective effects of induction of haem oxygenase-1 combined with increased adiponectin on the glomerular vascular endothelial growth factor-nitric oxide axis in obese rats. Exp. Physiol. 100, 865-876 https://doi.org/10.1113/EP085116

Livak KJ, Schmittgen TD (2001): Analysis of relative gene expression data using real-time quantitative PCR and the 2(-DDC (t)). Methods 25, 402-408 https://doi.org/10.1006/meth.2001.1262

Mahmoud IM, Hussein Ael-A, Sarhan ME, Awad AA, El Desoky I (2007): Role of combined L-arginine and prostaglandin E1 in renal ischemia-reperfusion injury. Nephron Physiol. 105, p57-65 https://doi.org/10.1159/000100425

Maines MD (1988): Heme oxygenase: function, multiplicity, regulatory mechanisms, and clinical applications. FASEB J. 2, 2557-2568 https://doi.org/10.1096/fasebj.2.10.3290025

Masini E, Vannacci A, Marzocca C, Pierpaoli S, Giannini L, Fantappié O, Mazzanti R, Mannaioni PF (2003) : Heme oxygenase-1 and the ischemia-reperfusion injury in the rat heart. Exp. Biol. Med. (Maywood) 228, 546-549 https://doi.org/10.1177/15353702-0322805-25

Mehta A, Sekhon CP, Giri S, Orak JK, Singh AK (2002): Attenuation of ischaemia-reperfusion induced MAP kinases by N-acetyl cysteine, sodium nitroprusside and phosphoramidon. Mol. Cell Biochem. 240, 19-29 https://doi.org/10.1023/A:1020675721351

Miyajima A, Chen J, Lawrence C, Ledbetter S, Soslow RA, Stern J, Jha S, Pigato J, Lemer ML, Poppas DP, Vaughan ED, Felsen D (2000): Antibody to transforming growth factor-beta ameliorates tubular apoptosis in unilateral ureteral obstruction. Kidney Int. 58, 2301-2313 https://doi.org/10.1046/j.1523-1755.2000.00414.x

Miyajima A, Asano T, Asano T, Yoshimura I, Seta K, Hayakawa M (2001): Tranilast ameliorates renal tubular damage in unilateral ureteral obstruction. J. Urol. 165, 1714-1718 https://doi.org/10.1016/S0022-5347(05)66400-2

Ndisang JF, Jadhav A (2014):Hemin therapy improves kidney function in male streptozotocin-induced diabetic rats: role of the heme oxygenase/atrial natriuretic peptide/adiponectin axis. Endocrinology 155, 215-229 https://doi.org/10.1210/en.2013-1050

Pararajasingam R, Weight SC, Bell PRF, Nicholson MR, Sayerst RD (2000): Prevention of renal impairment following aortic cross-clamping by manipulation of the endogenous renal NO response. Eur. J. Vasc. Endovasc. Surg. 19, 396-399 https://doi.org/10.1053/ejvs.1999.1030

Pinsky DJ, Oz MC, Koga S, Taha Z, Broekman MJ, Marcus AJ, Liao H, Naka Y, Brett J, Cannon PJ, Nowygrod R, Malinski T, Stern DM (1994): Cardiac preservation is enhanced in a heterotopic rat transplant model by supplementing the nitric oxide pathway. J. Clin. Invest. 93, 2291-2297 https://doi.org/10.1172/JCI117230

Rhoden EL, Rhoden CR, Lucas ML, Pereira-Lima L, Zettler C, Belló-Klein A (2002): The role of nitric oxide pathway in the renal ischaemia -reperfusion injury in rats. Transplant. Immunol. 10, 277-284 https://doi.org/10.1016/S0966-3274(02)00079-5

Saito M, Miyagawa I (2000): Real-time monitoring of nitric oxide in ischaemia -reperfusion injury rat kidney. Urol. Res. 28, $141-146$ https://doi.org/10.1007/s002400050153

Schnackenberg CG (2002): Physiological and pathophysiological roles of oxygen radicals in the renal microvasculature. Am. J. Physiol. Regul. Integr. Comp. Physiol. 282, R335-R342 https://doi.org/10.1152/ajpregu.00605.2001

Shokeir A.A, Hussein A.M, Barakat N, Abdelaziz A, Elgarba M, Awadalla A. (2014): Activation of nuclear factor erythroid 2-related factor 2 (Nrf2) and Nrf-2-dependent genes by ischaemic pre-conditioning and post-conditioning: new adaptive endogenous protective responses against renal ischaemia/reperfusion injury. Acta Physiol. (Oxf) 210, 342-353 https://doi.org/10.1111/apha.12164

Siegel PM, Massague J (2003): Cytostatic and apoptotic actions of TGF-beta in homeostasis and cancer. Nat. Rev. Cancer 3, $807-821$

https://doi.org/10.1038/nrc1208

Singh D, Chopra K (2004): The effect of naringin, a bioflavonoid on ischemia-reperfusion induced renal injury in rats. Pharmacol. Res. 50, 187-193 https://doi.org/10.1016/j.phrs.2004.01.007

Singh D, Chander V, Chopra K (2004): Carvedilol attenuates ischemia reperfusion-induced oxidative renal injury in rats. Fund. Clin. Pharmacol. 18, 627-634 https://doi.org/10.1111/j.1472-8206.2004.00279.x

Solez K, Kramer EC, Fox JA, Heptinstall RH (1974): Medullary plasma flow and intravascular leukocyte accumulation in acute renal failure. Kidney Int. 6, 24-37 https://doi.org/10.1038/ki.1974.74

Tome LA, Campos SB, Seguro AC (1994): Protective effect of L-arginine on post-ischemic acute renal failure. Kidney Int. 46, 1747

Tribukait B, Moberger G, Zetterberg A (1975): Methodological aspects of rapid-flow cytoflurometry for DNA analysis of human urinary bladder cells. European Press 1, 50-60

Vindelov L (1977): Flow microfluorimetric analysis of nuclear DNA in cells from solid tumors and cell suspensions: A new method for rapid isolation and staining of nuclei. Virchows Arch. 24, 227-242

Wagner M, Cadetg P, Ruf R, Mazzucchelli L, Ferrari P, Redaelli CA (2003): Heme oxygenase-1 attenuates ischemia/reperfusioninduced apoptosis and improves survival in rat renal allografts. Kidney Int. 63, 1564-1573 https://doi.org/10.1046/j.1523-1755.2003.00897.x

Wang G, Hamid T, Keith RJ, Zhou G, Partridge CR, Xiang X, Kingery JR, Lewis RK, Li Q, Rokosh DG, et al. (2010): Cardioprotective and antiapoptotic effects of heme oxygenase-1 in the failing heart. Circulation 121, 1912-1925 https://doi.org/10.1161/CIRCULATIONAHA.109.905471

Wangsiripaisan A, Gengaro PE, Nemenoff RA, Ling H, Edelstein CL, Schrier RW (1999): Effect of nitric oxide donors on renal tubular epithelial cell-matrix adhesion. Kidney Int. 55, 2281-2288 https://doi.org/10.1046/j.1523-1755.1999.00484.x 
Weight SC, Furness PN, Nicholson ML (1998): New model of renal warm ischaemia-reperfusion injury for comparative functional, morphological and pathophysiological studies. Br. J. Surg. 85, 1669-1673 https://doi.org/10.1046/j.1365-2168.1998.00851.x

Weight SC, Furness PN, Nicholson ML (1999): Biphasic role of nitric oxide in experimental renal warm ischaemia-reperfusion injury. Br. J. Surg. 86, 1039-1046 https://doi.org/10.1046/j.1365-2168.1999.01162.x

Weight SC, Waller JR, Bradley V, Whiting PH, Nicholeson ML (2001): Interaction of eicosanoids and nitric oxide in renal reperfusion injury. Transplantation 72, 614-619 https://doi.org/10.1097/00007890-200108270-00009

Wu D, Cederbaum AI (2003): Alcohol, oxidative stress, and free radical damage. Alcohol Res. Health 27, 277-284

Yeh CH, Chen TP, Wang YC, Lin YM, Lin PJ (2009): HO-1 activation can attenuate cardiomyocytic apoptosis via inhibition of
NF-kappaB and AP-1 translocation following cardiac global ischemia and reperfusion. J. Surg. Res. 155, 147-156 https://doi.org/10.1016/j.jss.2008.07.044

Yet SF, Tian R, Layne MD, Wang ZY, Maemura K, Solovyeva M, Ith B, Melo LG, Zhang L, Ingwall JS, Dzau VJ, Lee ME, Perrella MA (2001): Cardiac-specific expression of heme oxygenase-1 protects against ischemia and reperfusion injury in transgenic mice. Circ. Res. 89, 168-173 https://doi.org/10.1161/hh1401.093314

Yoshioka T, Ichikawa I (1989): Glomerular dysfunction induced by polymorphonuclear leukocyte-derived reactive oxygen species. Am. J. Physiol. 257, F53-59

https://doi.org/10.1152/ajprenal.1989.257.1.F53

Received: December 8, 2016

Final version accepted: April 24, 2017 